\title{
CHROMOSOMAL ANALYSIS OF RABBITS DERIVED FROM EGGS FERTILIZED IN VITRO
}

\author{
LYNN R. FRASER, ${ }^{*}$ GILLIAN R. PATON* AND R. D. BARNES* \\ * Department of Infant Development, Clinical Research Centre, \\ Harrow, Middlesex HA1 $3 U \mathcal{H}$, and \\ $\dagger$ Department of Obstetrics and Gynaecology, University College Hospital, London
}

(Received 4th October 1974)

There has been considerable interest in recent months in the possibility of using fertilization in vitro and embryo transfer techniques to alleviate certain forms of human infertility.

These techniques have been used successfully in the rabbit (Chang, 1959; Fraser \& Dandekar, 1973), mouse (Whittingham, 1968; Hoppe \& Pitts, 1973) and rat (Toyoda \& Chang, 1974). In general, relatively few embryos have been transferred and little reference to the offspring has been made other than to note phenotypic normality. Fertilization in vitro has also been described for human eggs (Edwards, Steptoe \& Purdy, 1970) and more than twelve such eggs have subsequently been transplanted (Robertson, 1974), although no pregnancies have yet been reported (de Kretzer \& co-authors, 1973). The reasons for failure are unknown, but the possibility exists that fertilization in vitro may increase the chances for union of defective or abnormal gametes. Under conditions of natural mating, relatively few spermatozoa from the ejaculate reach the site of fertilization (Piko, 1969), and there are opportunities for sperm selection (Krzanowska, 1974), but with fertilization in vitro, all spermatozoa presumably have an equal opportunity to fertilize an egg. It is, therefore, desirable that experimental data comparing the incidence of abnormalities in the products of eggs fertilized in vivo and in vitro be determined before the techniques of fertilization in vitro and embryo transfer are applied to man.

Toyoda \& Chang (1974) examined the offspring derived from rat eggs fertilized in vitro. These authors reported that eleven of twenty-two rats showed signs of microphthalmia while the defect was not seen in a group of control animals of similar size. Development of microphthalmia in the rat apparently involves both genetic and physiological factors (Hain, 1937). In a study of fourteen rabbits derived from eggs fertilized in vitro, Fraser \& Dandekar (1973) described two animals with splayleg. None was found in a similar number of control rabbits derived from naturally fertilized eggs cultured in vitro and transferred to pseudopregnant recipients. There is no information on the natural incidence of splayleg in rabbits, but the defect is known to be inherited and dependent on a recessive autosomal gene (Innes \& O'Steen, 1957).

We have studied the chromosomes in ten of the twelve phenotypically normal experimental rabbits mentioned above (Fraser \& Dandekar, 1973). As controls, two age-matched naturally bred New Zealand rabbits were examined. Blood, 
skin, spleen and bone marrow cultures were analysed. Whole blood $(0.2 \mathrm{ml})$ was cultured in $5 \mathrm{ml}$ Eagles Minimal Essential Medium (Flow Labs) containing $10 \%$ fetal calf serum and $2 \%$ phytohaemagglutinin (Burroughs Wellcome) for 48 or $72 \mathrm{hr}$. Skin biopsies were cultured in Dulbecco's Minimal Essential Medium (Flow Labs) and the fibroblast cells were examined before the tenth passage. All cultures were tested for mycoplasma contamination. Direct preparations were made from spleen and bone marrow cells obtained at autopsy (Fialkow, Paton \& East, 1973).

The results of the analyses are presented in Table 1 . The majority of cells were found to have a normal chromosome count of 44 , although in fibroblast

Table 1. Chromosome analyses of ten rabbits derived from eggs fertilized in vitro and two control rabbits

\begin{tabular}{|c|c|c|c|c|c|}
\hline \multirow{2}{*}{ Tissue } & \multirow{2}{*}{$\begin{array}{c}\text { No. of } \\
\text { animals studied }\end{array}$} & \multicolumn{4}{|c|}{$\begin{array}{l}\text { No. of cells with } \\
\text { chromosome counts of : }\end{array}$} \\
\hline & & 42 & 43 & 44 & 45 \\
\hline \multicolumn{6}{|l|}{ Gontrol } \\
\hline Spleen & - & - & - & - & 二 \\
\hline $\begin{array}{l}\text { Bone marrow } \\
\text { Blood culture }\end{array}$ & $\overline{2}$ & $\overline{7}$ & $\overline{6}$ & $\overline{40}$ & 0 \\
\hline Skin culture & 2 & 7 & 10 & 72 & 1 \\
\hline \multicolumn{5}{|l|}{ Experimental } & \\
\hline Spleen & 6 & 5 & 11 & 101 & $\begin{array}{l}0 \\
0\end{array}$ \\
\hline Bone marrow & 9 & 18 & 17 & 230 & $\begin{array}{l}0 \\
0\end{array}$ \\
\hline Skin culture & $\stackrel{\circ}{9}$ & 29 & 56 & 516 & 12 \\
\hline
\end{tabular}

The incidence of aneuploidy in experimental and control preparations is not significantly different, using the $\chi^{2}$ test where $P=0.05$. Hypoploidy is likely to be a technical artifact.

cultures from four of the ten experimental animals, one to three cells with 45 chromosomes were seen. In all, a total of $12 / 613(2 \%)$ hyperploid cells were seen compared with $1 / 90(1 \%)$ in the two control animals. The extra chromosome in the hyperploid cells was identified when possible and the abnormality was not repeated within abnormal cells from the same rabbit. D. Yang (personal communication) has suggested that the chromosome number of rabbit cells may be more unstable in culture than other mammalian cells. Our results are in agreement with this suggestion.

Structurally abnormal chromosomes such as dicentrics, acentric fragments, ring chromosomes and triradial configurations were seen in occasional cells from fibroblast cultures, but never in cells from direct preparations of spleen and bone marrow, or from the short-term cultures of lymphocytes. These abnormalities are thought to have arisen in culture, although none was seen in cells cultured from the control animals.

Cells with simple chromatid breaks were rarely seen in metaphases from spleen, bone marrow and blood cultures. In skin cultures, the incidence of cells with chromatid breaks from eight experimental and two control animals was 
less than $2 \%$ but, in the remaining two experimental animals, the incidence of chromatid breakage was higher: $6 \%$ of fifty-six cells and $19 \%$ of sixty-seven cells. Contamination of the cultures by mycoplasma was considered as a causative factor (Paton, Jacobs \& Perkins, 1965). Two of the twelve cultures were found to be positive for Mycoplasma hyorhinis, but though one of these had a high incidence of breakage (19\%), only one break was seen in ninety-five cells from the other.

The analyses of chromosomes from direct preparations of spleen and bone marrow cells and from short-term leucocyte cultures revealed normal cells with a chromosome count of 44. Again, no abnormalities were recorded. Although abnormal cells were occasionally seen in cells cultured from skin biopsies of experimental and control animals, it is probable that these abnormalities arose in culture. In all cases, the majority of cells had a normal karyotype, and it is concluded that the chromosomes of these ten rabbits derived from eggs fertilized in vitro were normal.

The chromosomal analyses of this small sample of experimentally derived rabbits excluded the possibility that a normal phenotype was masking an abnormality such as mosaicism. In man, certain individuals mosaic for trisomy 21 are phenotypically normal and, in some cases, trisomic cells have been detected only in the skin cultures (Taylor, 1970). The splayleg condition in rabbits (Fraser \& Dandekar, 1973) and the microphthalmia in rats (Toyoda \& Chang, 1974) involve genetic defects which would be undetectable with the technique used in the present study.

More studies including analyses for known genetic defects as well as chromosomal abnormalities should be carried out on pre- and post-implantation stages, following fertilization in vitro, in various laboratory animals. The finding that these ten experimental rabbits were normal is an initial step in the thorough evaluation of embryos and offspring derived from fertilization in vitro which is necessary before the techniques, including embryo transfer, are applied to man.

Our thanks are due to Miss M. Silver for technical assistance, and to Dr D. Taylor-Robinson for the mycoplasma tests. One of us (G.R.P.) is a visiting worker at the Clinical Research Centre, and is a member of the Medical Research Council's External Scientific Staff.

\section{REFERENCES}

Chang, M. (1959) Fertilization of rabbit ova in vitro. Nature, Lond. 184, 466-467.

de Kretzer, D., Dennis, P., Hudson, B., Leeton, J., Lopata, A., Outch, K., Talbot, J. \& Wood, G. (1973) Transfer of a human zygote. Lancet, ii, 728-729.

Edwards, R., Steptoe, P. \& Purdy, J. (1970) Fertilization and cleavage in vitro of preovulatory human oocytes. Nature, Lond. 227, 1307-1309.

Fialkow, P., Paton, G. \& EAst, J. (1973) Chromosomal abnormalities in spleens of New Zealand black mice, a strain characterized by autoimmunity and malignancy. Proc. natn. Acad. Sci. U.S.A. 70, 1094-1098.

Fraser, L. \& Dandekar, P. (1973) The effects of aging on in vitro fertilization of rabbit eggs and subsequent embryonic development. F. exp. Zool. 184, 303-312.

Hain, A. (1937) Microphthalmia and other eye-defects throughout fourteen generations of albino rats. Proc. R. Soc. Edinb, 57, 64-77.

Hoppe, P. \& Prtrs, S. (1973) Fertilization in vitro and development of mouse ova. Biol. Reprod. 8, 420426. 
INNES, J. \& O'STEEN, W. (1957) Splayleg in rabbits. An inherited disease analogous to joint dysplasia in children and dogs. Lab. Invest. 6, 171-186.

KRZANOWSKA, H. (1974) The passage of abnormal spermatozoa through the uterotubal junction of the mouse. 7. Reprod. Fert. 38, 81-90.

Paton, G., Jacobs, J. \& Perkins, F. (1965) Chromosome changes in human diploid cell cultures infected with mycoplasma. Nature, Lond. 207, 43-45.

PIKo, L. (1969) Gamete structure and sperm entry in mammals. In Fertilization, Vol. 2, pp. 325-403. Eds. C. Metz and A. Monroy. Academic Press, New York.

Robertson, M. (1974) Those babies still pose problems. Nature, Lond. 250, 368.

TAYLOR, A. (1970) Further observations of cell selection in vivo in normal/G trisomic mosaics. Nature, Lond. 227, 163-164.

Toyoda, Y. \& Chang, M. (1974) Fertilization of rat eggs in vitro by epididymal spermatozoa and the development of eggs following transfer. F. Reprod. Fert. 36, 9-22.

Whittingham, D. (1968) Fertilization of mouse eggs in vitro. Nature, Lond. 220, 592-593. 